\title{
Abraham Guillén: A Relevant Theory for Contemporary Guerrilla Warfare
}

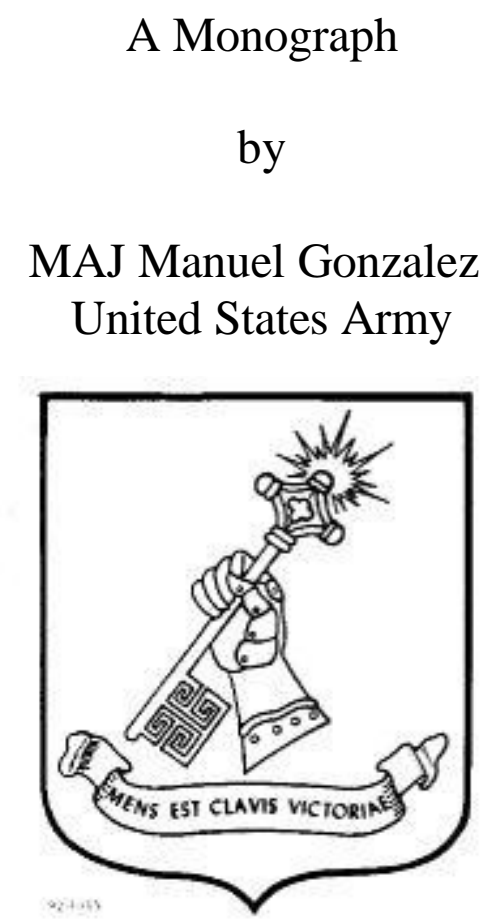

School of Advanced Military Studies

United States Army Command and General Staff College

Fort Leavenworth, Kansas

\section{5-01}

Approved for public release; distribution is unlimited. 


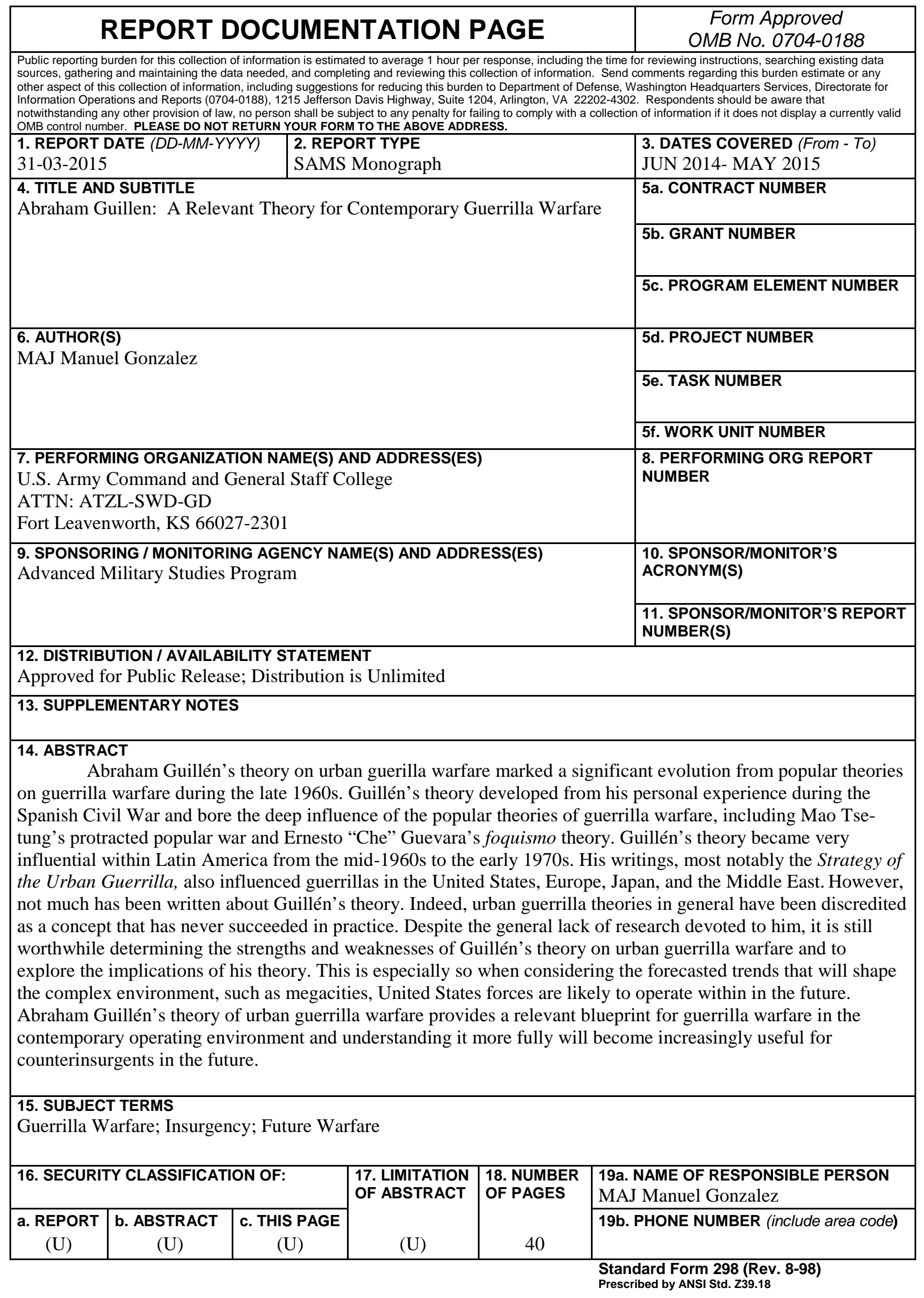




\section{Monograph Approval Page}

Name of Candidate: MAJ Manuel Gonzalez

Monograph Title: $\quad$ Abraham Guillén: A Relevant Theory for Contemporary Guerrilla Warfare

Approved by:

Monograph Director

Ricardo A. Herrera, PhD

, Seminar Leader

Craig Berryman, COL

, Director, School of Advanced Military Studies

Henry A. Arnold III, COL

Accepted this 23rd day of May 2015 by:

Robert F. Baumann, PhD

, Director, Graduate Degree Programs

The opinions and conclusions expressed herein are those of the student author and do not necessarily represent the views of the US Army Command and General Staff College or any other governmental agency. (References to this study should include the foregoing statement.) 


\begin{abstract}
Abraham Guillén: A Relevant Theory for Contemporary Guerrilla Warfare, by MAJ Manuel Gonzalez, 40 pages.

Abraham Guillén's theory on urban guerilla warfare marked a significant evolution from popular theories on guerrilla warfare during the late 1960s. Guillén’s theory developed from his personal experience during the Spanish Civil War and bore the deep influence of the popular theories of guerrilla warfare, including Mao Tse-tung's protracted popular war and Ernesto “Che” Guevara's foquismo theory. Guillén's theory became very influential within Latin America from the mid1960s to the early 1970s. His writings, most notably the Strategy of the Urban Guerrilla, also influenced guerrillas in the United States, Europe, Japan, and the Middle East. However, not much has been written about Guillén's theory. Indeed, urban guerrilla theories in general have been discredited as a concept that has never succeeded in practice. Despite the general lack of research devoted to him, it is still worthwhile determining the strengths and weaknesses of Guillén's theory on urban guerrilla warfare and to explore the implications of his theory. This is especially so when considering the forecasted trends that will shape the complex environment, such as megacities, United States forces are likely to operate within in the future. Abraham Guillén's theory of urban guerrilla warfare provides a relevant blueprint for guerrilla warfare in the contemporary operating environment and understanding it more fully will become increasingly useful for counterinsurgents in the future.
\end{abstract}




\section{Contents}

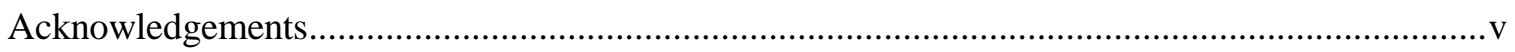

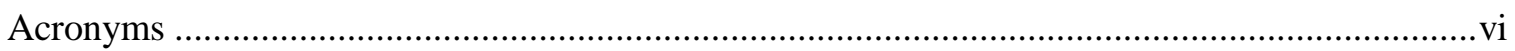

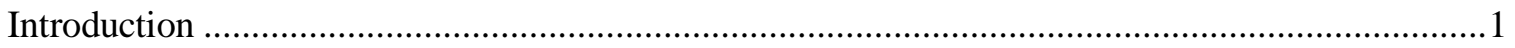

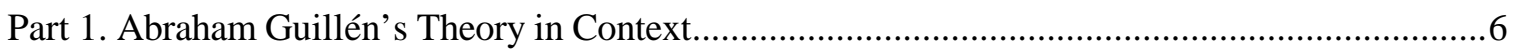

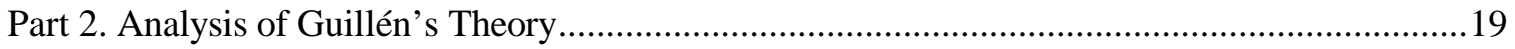

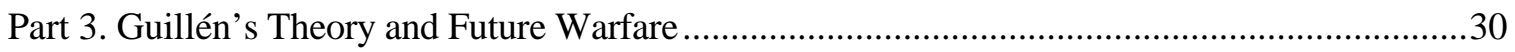

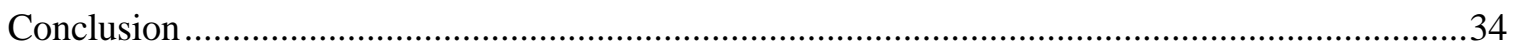

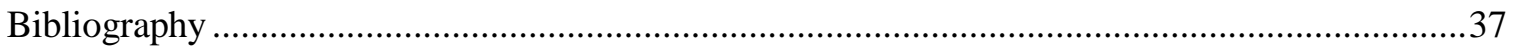




\section{Acknowledgements}

To my wife and daughter. You are the source of my inspiration and motivation. I love you both with all my heart. Thank you for making all things in my life wonderful. 
Acronyms

$\begin{array}{ll}\text { CCP } & \text { Chinese Communist Party } \\ \text { FARC } & \text { Fuerzas Armadas Revolucionarias de Colombia } \\ \text { FM } & \text { Field Manual } \\ \text { IJA } & \text { Imperial Japanese Army } \\ \text { KMT } & \text { Kuomintang } \\ \text { MLN-T } & \text { Movimiento de Liberacion Nacional-Tupamaros } \\ \text { MNT } & \text { Movimiento Nacionalista Tacuara } \\ \text { PIRA } & \text { Provisional Irish Republican Army } \\ \text { UK } & \text { United Kingdom } \\ \text { UN } & \text { United Nations } \\ \text { US } & \text { United States }\end{array}$


Introduction

The strategy of revolutionary war is essentially political: if it does not begin with a broad front of liberation, the guerrillas will lose the war strategically, regardless of tactical successes, from failure to obtain the support of the great mass of the population of an underdeveloped country.

Abraham Guillén, $1966^{1}$

\section{Major Research Question}

At the height of the development of guerrilla warfare theory in 1971, RAND analyst Brian M. Jenkins stated, “no great theorist of urban guerrilla warfare has appeared. There is no Mao of the city.”² To be sure, Abraham Guillén may not be as influential as Mao Tse-tung, however his theory on guerilla warfare marked a significant evolution from popular theories during the late 1960s, fusing the classic rural strategy with the urban strategy. Guillén's theory developed from his personal experience during the Spanish Civil War and bore the deep influence of the popular theories of guerrilla warfare, including Mao Tse-tung's protracted popular war and Ernesto “Che” Guevara’s foquismo theory. However, not much has been written about Guillén’s theory. Indeed, urban guerrilla theories in general have been discredited as a concept that has never succeeded in practice. Despite Jenkins’s dismissal of Guillén and the general lack of research devoted to him, it is still worthwhile determining the strengths and weaknesses of Guillén's theory on urban guerrilla warfare and to explore the implications of his theory. This is especially so when considering the forecasted trends that will shape the complex environment, such as megacities, United States forces are likely to operate within in the future. Abraham Guillén's theory of urban guerrilla warfare provides a relevant blueprint for guerrilla warfare in

${ }^{1}$ Abraham Guillén, Philosophy of the Urban Guerrilla: The Revolutionary Writings of Abraham Guillén, trans. and ed. by Donald C. Hodges (New York: William Morrow, 1973), 253.

${ }^{2}$ Brian M. Jenkins's reference to a "Mao of the city" is in recognition of the widely held belief that Mao Tse-tung's theory for protracted popular revolution is one of the most influential theories of guerrilla warfare. Brian Michael Jenkins, An Urban Strategy for Guerrillas and Governments (Santa Monica, CA: RAND, 1975), 3. 
the contemporary operating environment and understanding it more fully will become increasingly useful for counterinsurgents in the future.

Significance of the Research Question

Abraham Guillén’s theory was influential at the time of his writing from the mid-1960s to the early 1970s. Guillén was the chief strategist for the Movimiento de Liberacion NacionalTupamaros (MLN-T), one of the earliest urban-based guerrilla group that operated in Montevideo, Uruguay from the mid-1960s to mid-1970s. ${ }^{3}$ His writings, most notably the Strategy of the Urban Guerrilla, influenced guerrillas in the United States, Europe, Japan, and the Middle East. ${ }^{4}$ Most famously, it influenced the Provisional Irish Republican Army’s (PIRA) strategy in Northern Ireland during the 1970s. Through the 1960s, the PIRA had attempted to employ a rural strategy influenced by the protracted popular war and foquismo theories. After experiencing political and military failure, the PIRA adjusted their practicing strategy to a more urban-based strategy espoused by Guillén. ${ }^{5}$ It reorganized from a conventional military hierarchy to a cellular based network as prescribed by Guillén and other urban theorists. ${ }^{6}$ Unprepared for this type of warfare, the United Kingdom's overly militarized and heavy-handed counter-insurgency strategy

${ }^{3}$ Anthony James Joes, Urban Guerrilla Warfare (Lexington: University Press of Kentucky, 2007), 82-83; Ben Connable and Martin C. Libicki, How Insurgencies End (Santa Monica, CA: RAND, 2010), 94.

${ }^{4}$ Bard E. O’Neill, Insurgency and Terrorism: From Revolution to Apocalypse, 2nd ed. (Dulles, VA: Potomac Books, 2005), 61-62.

${ }^{5}$ Timothy D. Hoyt, “Adapting to a Changing Environment: The Irish Republican Army as an Armed Group," in Armed Groups: Studies in National Security, Counterterrorism, and Counterinsurgency, ed. Jeffrey H. Norwitz (Newport, RI: US Naval War College, 2008), 50.

${ }^{6}$ Peter R. Neumann, Old and New Terrorism: Late Modernity, Globalization and the Transformation of Political Violence (Malden, MA: Polity Press, 2009), 29-31; Carlos Marighella," Minimanual of the Urban Guerrilla," in Terror and Urban Guerrillas: A Study of Tactics and Documents, ed. Jay Mallin (Coral Gables, FL: University of Miami Press, 1982), 8081; Guillén, Philosophy of the Urban Guerrilla, 240-241. 
alienated the population and fed into the PIRA narrative, intensifying the conditions that generated the insurgency. ${ }^{7}$

Among contemporary insurgencies, Guillén’s theory remains relevant today. After sustaining major military losses in the late 1990s and early 2000s, the Fuerzas Armadas Revolucionarias de Colombia (FARC) began seeking external assistance to improve its ability to conduct insurgency operations. The FARC, historically a rural-based insurgency, received training from the PIRA in urban guerrilla warfare between 2002 and $2004{ }^{8}$ The FARC began a renewed insurgency campaign, beginning in 2005, with increasingly effective operations within urban areas; a new trend that alarmed Colombian security forces. ${ }^{9}$ The FARC's connection to Guillén is indirect; however, Guillén’s theory influenced the training provided by the PIRA much as the theories of Antoine-Henri Jomini and Carl von Clausewitz influence US Army doctrine. Interestingly, experts believe that the PIRA had been sharing its knowledge with other organizations for decades. ${ }^{10}$

It is likely that Guillén’s theory will be increasingly relevant in the future. In 1995, terrorism and insurgency experts Jennifer Morrison Taw and Bruce Hoffman warned of a continuation of the trends that gave rise to Guillén’s theory, stating that “a demographic upheaval

${ }^{7}$ Maria Jose Mayano Rasmussen, The Military Role in Internal Defense and Security: Some Problems (Monterey, CA: Center for Civil-Military Relations, Naval Postgraduate School, 1999), 17-33; Gary LaFree, "Efficacy of Counterterrorism Approaches: Examining Northern Ireland," National Consortium for the Study of Terrorism and Responses to Terrorism, University of Maryland, October 2006. Accessed 24 July 2014. http://www.start.umd.edu/sites/default/ files/files/publications/research_briefs/20061017_lafree.pdf.

${ }^{8}$ Kim Cragin, Peter Chalk, Sara A. Daly, and Brian A. Jackson, Sharing the Dragon's Teeth: Terrorist Groups and the Exchange of New Technologies (Santa Monica, CA: RAND, 2007), 71-73.

9 “Fuerzas Armadas Revolucionarias de Colombia (FARC),” Jane’s World Insurgency and Terrorism Database, 7 March 2014. Accessed 17 November 2015. https://janes.ihs.com/ CustomPages/Janes/DisplayPage.aspx?DocType=Reference\&ItemId=+++1320752.

${ }^{10}$ James J. F. Forest, "Knowledge Transfer and Shared Learning among Armed Groups," in Armed Groups: Studies in National Security, Counterterrorism, and Counterinsurgency, 272. 
of seismic proportions is today transforming almost the entire developing world from a predominantly rural society to an urban one.” ${ }^{11}$ More recent research predicts an increase in global population from the roughly 7.1 billion that exist today to 9.1 billion by 2050, with approximately 75 percent living in urban areas. ${ }^{12}$ It is prudent to anticipate that complex urbanization challenges may act as accelerants for future conflicts and could shape tomorrow's battlefield. Thus, Abraham Guillén’s theory provides a valuable insight into how future adversaries may organize, operate, and adapt in the increasingly complex future environment that US forces are likely to operate within.

\section{Literature Review}

Several analysts have discredited urban guerrilla movements as flawed strategies. In a 1971 RAND report, Brian Jenkins states, “urban guerrillas can offer few successes to be emulated by other urban guerrillas. They have not taken a single city. They have not overthrown a single government.”13 In 1977, Walter Laqueur, one of the most prolific writers on guerrilla warfare, wrote "urban terror certainly creates much noise and causes some destruction and indiscriminate killing. Its political significance, however, is very much in doubt.” ${ }^{14}$ Experts continue to maintain this view in more recent research. In 2005, Bard O’Neill, a leading expert in counterinsurgency, stated "with the exception of South Yemen in 1967, the urban-warfare strategy has been

\footnotetext{
${ }^{11}$ Jennifer Morrison Taw and Bruce Hoffman, "The Urbanization of Insurgency: Potential Challenges to US Army Operations,” Small Wars and Insurgencies 6 (Spring 1995): 68.

${ }^{12}$ David Kilcullen, Out of the Mountains: The Coming Age of the Urban Guerrilla (Oxford: Oxford University Press, 2013), 28-29.

${ }^{13}$ Brian Michael Jenkins, The Five Stages of Urban Guerrilla Warfare: Challenges of the 1970s (Santa Monica, CA: RAND, 1971), 4.

${ }^{14}$ Walter Laqueur, The Guerrilla Reader: A Historical Anthology (Philadelphia: Temple University Press, 1977), 8.
} 
ineffective.” ${ }^{15}$ In 2007, urban guerrilla warfare expert, Anthony J. Joes concludes “nowhere in the twentieth century has urban guerrilla warfare achieved an unambiguous success.” ${ }^{16}$ On this point there is near universal agreement by experts.

Abraham Guillén is largely unknown. With the exception of Donald C. Hodges compilation of Guillén's writings, Philosophy of the Urban Guerrilla, there has been no significant study of Guillén or his theory. ${ }^{17}$ In Max Boot's popular history of guerrilla warfare, Invisible Armies, he discusses Ernesto Guevara, Regis Debray, and Carlos Marighella, but does not mention Abraham Guillén. ${ }^{18}$ Bard O’ Neill’s authoritative study on guerrilla warfare, Insurgency and Terrorism, only mentions Guillén once, oversimplifying Guillén’s view on urban and rural operations. ${ }^{19}$

Abraham Guillén is also often misunderstood. For example, RAND researchers Ben Connable and Martin C. Libicki point to Guillén's writing in Problems of Revolutionary Strategy, in which they highlight that Guillén does not stress the importance of sanctuary in the early phases of insurgency. ${ }^{20}$ To be fair, Guillén tends to contradict himself on the topic of sanctuary. However, in “Challenge to the Pentagon,” Guillén recommends building liberated zones in rural areas as soon as the insurgency is strong enough to maintain them. ${ }^{21}$ Much of the research on Guillén in other studies of guerrilla movements is limited to pithy quotes taken out of context.

${ }^{15}$ O’Neill, Insurgency and Terrorism, 62.

${ }^{16}$ Joes, Urban Guerrilla Warfare, 157.

${ }^{17}$ Donald C. Hodges, Philosophy of the Urban Guerrilla.

${ }^{18}$ Ernesto Guevara and Regis Debray were the leading theorists of the foquismo theory. Carlos Marighella formulated a theory of urban guerrilla warfare that complimented the rural foquismo theory. Max Boot, Invisible Armies: An Epic History of Guerrilla Warfare from Ancient Time to the Present (New York: W.W. Norton, 2013), 440-449.

${ }^{19}$ O’Neill, Insurgency and Terrorism, 62.

${ }^{20}$ Connable and Libicki, How Insurgencies End, 38.

${ }^{21}$ Abraham Guillén, Philosophy of the Urban Guerrilla, 286. 
Hypothesis

Guillén’s theory of urban guerrilla warfare provides a relevant blueprint for insurgency in the contemporary operating environment. Considering the future trends shaping the most likely type of warfare in the future, Guillén’s theory becomes increasingly important to understand. The most important of these trends is the combination of population growth and urbanization. This trend has been consistent since the industrial revolution, and only accelerated after World War II. Guillén recognized this trend and designed his theory to address it. Guillén may not yet be the Mao of the city, but predicted conditions in the future may add relevance to his theory, making him as influential as Mao Tse-tung.

\section{Abraham Guillén's Theory in Context}

Not very much is known about Abraham Guillén, despite being a prolific writer and commentator between 1960 and his death in Madrid, Spain in 1993. ${ }^{22}$ Guillén’s worldview, best described as neo-Marxist, was deeply influenced by aspects of anarchism and libertarianism. ${ }^{23}$ As an author, he published over 20 books and hundreds of articles on economics, politics, history, philosophy, as well as guerrilla warfare. ${ }^{24}$ His literary history can be broken down into two distinct areas of focus. Guillén begins and ends his life in the first focus area, as a political and economic philosopher concerned with capitalism and its negative impact on Latin America and Spain. Guillén's work in the second focus area, of which he is most known for, is the development of a theory for urban guerrilla warfare. To better understand Guillén’s theory, it is

${ }^{22}$ Guillén returned to Spain after the death of Francisco Franco in 1975.

${ }^{23}$ Hodges, Philosophy of the Urban Guerrilla, 4.

${ }^{24}$ VV . AA, “Biografía de Abraham Guillén: un economist libertario,” Portal Libertario Oaca, 4 September 2011. Accessed 17 December 2014. http://www.portaloaca.com/historia/ biografias/3382-biografia-de-abraham-Guillén-un-economista-libertario.html. 
prudent to start with his personal history and the evolution of the dominate guerrilla theories during that time. It is from this context that Guillén developed his theory for urban guerrilla warfare.

\section{Biography}

Abraham Guillén was born in Guadalajara, Spain on 13 March 1913 and grew up in a peasant family that struggled to make a living as farmers on land they did not own. Attending university in Madrid on an economics scholarship, the experience of his childhood propelled Guillén toward anti-establishment and revolutionary organizations that advocated change to the social, political, and economic order of Spain. ${ }^{25}$ Guillén’s experience as a guerrilla began with his participation in the Spanish Civil War in 1936. Guillén fought against the rebel fascist forces under Francisco Franco, participating in both urban and rural campaigns. ${ }^{26}$ Membership in a Spanish anarchist group under the leadership of Buenaventura Durruti, widely considered a hero of the Spanish Civil War, dramatically influenced Guillén’s views on guerrilla warfare. Durruti’s success as a leader and strategist demonstrated the importance of political organization and how to employ violence for political gain. ${ }^{27}$

Captured by government forces in 1939, Guillén fled to France in 1945 after two earlier attempts to escape prison. ${ }^{28}$ In 1948, he immigrated to Argentina where he became an editor for an economics newspaper and commentator on international politics in several leftist publications, espousing an anti-imperialist message. During this period, Guillén became an advisor to the

${ }^{25}$ William Daniel Nanez, “Abraham Guillén: The Remote Origins of the Personist Guerrilla 1955-1960,” El Ortiba, February 4, 2015. Accessed February 4, 2015; VV. AA, "Biografía de Abraham Guillén."

${ }^{26}$ Hodges, Philosophy of the Urban Guerrilla, 3-4.

${ }^{27}$ Ibid.

${ }^{28}$ VV. AA, ““Biografía de Abraham Guillén.” 
Movimiento Nacionalista Tacuara (MNT), an Argentine nationalist guerrilla movement, sharing his knowledge of guerrilla warfare gained in Spain. Pushed out of journalism due to his radical views, Guillén was arrested in 1961 for suspicion of supporting the Tucuaras. ${ }^{29}$ Shortly after his release, Guillén fled to Montevideo, Uruguay where he became an advisor to the Movimiento de Liberacion Nacional-Tupamaros (MLN-T) between 1964 and $1966 .{ }^{30}$ While advising the Tupamaros, Guillén would begin to formulate his theory for urban guerrilla warfare.

Dominance of the Rural Guerrilla Theories

Guillén’s increased involvement in Latin American insurgencies in the late 1950s to early 1970s coincided with an explosion of guerrilla warfare theory and practice in a period appropriately referred to as the "golden age of insurgency." ${ }^{31}$ Rural-based guerrilla warfare became the dominant theory guiding insurgencies from the early 1940s through the mid-1960s with Mao Tse-Tung’s and Fidel Castro’s successful rural insurgencies in China and Cuba standing as examples of success. To understand Guillén’s theory for urban guerrilla warfare, it is important to have a general understanding of the dominant theories that informed his thinking.

Mao Tse-tung is widely considered one of the most influential theorists of guerrilla warfare and his theory of protracted revolutionary warfare provides a theoretical base for most modern insurgencies. Before Mao developed his theory, the Chinese Communist Party (CCP) had conducted its insurgency according to Soviet doctrine developed from the Russian October Revolution in $1917 .^{32}$ Influenced by Soviet advisors, the CCP pursued a strategy based on the

\section{${ }^{29}$ Hodges, Philosophy of the Urban Guerrilla, 5-7.}

${ }^{30}$ Joes, Urban Guerrilla Warfare, 82-83; Connable and Libicki, How Insurgencies End, 94.

${ }^{31}$ Steven Metz and Raymond Millen, Insurgency and Counterinsurgency in the 21st Century: Conceptualizing Threat and Response (Carlisle, PA: Strategic Studies Institute, 2004), 8; Boot, Invisible Armies, 449.

32 O’Neill, Insurgency and Terrorism, 49. 
belief that "only a mass movement led by the industrial proletariat could be truly revolutionary.” ${ }^{33}$ With disastrous results, the CCP attempted to conduct a rapid urban-based uprising, paying little attention to the countryside. ${ }^{34}$

In formulating a new theory for revolutionary warfare, Mao recognized the differences between 1917 Russia and 1930s China and nullified Soviet doctrine as the definitive Communist guide to Chinese revolution. In his writings he recognizes "a few modern industrial and commercial cities coexist with a vast stagnant countryside; several million industrial workers coexist with several hundred millions of peasants.”35 The Communist revolution in China would have to be peasant based and rural. Additionally, Mao recognized the relative weakness of the CCP, advocating for a phased protracted struggle that focused on establishing a political base that would enable a gradual increase in strength. The increase in strength would enable a shift from a political and military organizing phase to a guerrilla warfare phase and finally to a conventional phase in which the CCP could defeat the conventional forces of the Imperial Japanese Army (IJA) and Kuomintang (KMT). ${ }^{36}$ The cities would be avoided until the final phases of the protracted struggle. ${ }^{37}$

Employing the strategy espoused by Mao Tse-tung, the Chinese Communists defeated both the IJA by 1945 and the KMT on the Chinese mainland by 1949. Although Mao

${ }^{33}$ Walter Laqueur, Guerrilla Warfare: A Historical and Critical Study (New Brunswick, NJ: Transaction Publishers, 1998), 243.

${ }^{34}$ Ian F.W. Beckett, Modern Insurgencies and Counter-Insurgencies: Guerrillas and their Opponents since 1750 (New York: Routledge, 2001), 70-71.

${ }^{35}$ Mao Tse-tung, "Problems of Strategy in China’s Revolutionary War," in Selected Works of Mao Tse-tung, vol. 1 (Peking: Foreign Languages Press). http://www.marxists.org/reference/archive/mao/selected-works/volume-1/mswv1_12.htm.

${ }^{36}$ Mao Tse-tung, "The Three Stages of the Protracted War," in The Guerrilla Reader: A Historical Anthology, 189-193.

${ }^{37}$ Lin Piao, "Encircling the Cities of the World," in The Guerrilla Reader: A Historical Anthology, 199. 
acknowledged that his theory of guerrilla warfare was designed for the Chinese experience, he believed his theory provided a universal framework that could be applied anywhere in the world. While formulating his theory for guerrilla warfare, Mao writes, "we must point out that the guerrilla campaigns being waged in China today are a page in history that has no precedent. Their influence will not be confined solely to China in her present anti-Japanese war but will be worldwide.” 38 As stated by Bard E. O’Neill, “[Mao’s] strategy became increasingly attractive to insurgents around the world because it offered them a cohesive, systematic blueprint for their own struggles against colonial occupiers or oppressive indigenous regimes.”39 Mao’s principles of operating among the peasants in rural areas through the three phases of revolutionary warfare proliferated globally and became the foundation of numerous insurgencies throughout the 1950s and 1960s.

In the early 1960s, Ernesto “Che” Guevara developed the foquismo theory. Unlike Mao, who developed his theory of action when available theory failed, Che developed the foquismo theory based largely on his observations and reflections of the Cuban Revolution. His theory can be broken down into three principles: popular forces can win against the army, the insurrection can create conditions for revolution, and the countryside is the best area for waging an insurgency. ${ }^{40}$ Like Mao, his theory was peasant-based, rural, and protracted across three phases. However, unlike Mao, Che did not think it was necessary to develop the political base that was the nucleus of Mao's protracted popular revolution. ${ }^{41}$ Popular support was built through military

${ }^{38}$ Mao Tse-tung, On Guerrilla Warfare, trans. Samuel B. Griffith (Mineola, NY: Dover, 2005), 65.

${ }^{39}$ O’Neill, Insurgency \& Terrorism, 50.

${ }^{40}$ Ernesto Guevara, Guerrilla Warfare (New York: Monthly Review Press, 1961), 7.

${ }^{41}$ Jose A. Moreno, "Che Guevara on Guerrilla Warfare: Doctrine, Practice, and Evaluation,” Comparative Studies in Society and History 12, no. 2 (April 1970): 118-119. 
victory, not political organization. ${ }^{42}$ Che argued that a small devoted band of revolutionaries, the guerrilla foco, would automatically attract the support of the peasants, whom the foco would lead militarily and politically to victory. The city was perceived as the "graveyard of revolutionaries;" the proletariat was only important in the post revolution phase..$^{43}$

Just as the Communist Revolution in China validated Mao's theory of protracted popular revolution, the success of the Cuban Revolution seemingly validated Che's foquismo theory. Although he states that his theory offers "an outline, not a bible," Che fully intended his theory to be applied globally, famously stating, "I would like to start two, three, many Vietnams." ${ }^{44} \mathrm{He}$ personally applied his theory, leading insurgencies in the Congo in 1964 and Bolivia in 1967, albeit without success.

From the 1950s to 1960s, rural insurgencies inspired by Mao’s and Che’s theories spawned “an epidemic of revolutionary violence” throughout Latin America, Africa, and Asia. ${ }^{45}$ However, by the mid-1960s, a wave of unsuccessful insurgencies brought the efficacy of rural guerilla warfare theory into question. ${ }^{46}$ Insurgencies influenced by Mao’s theory failed in the Philippines in 1954, Malaysia in 1960, and Thailand by $1970 .{ }^{47}$ Insurgencies influenced by Che's theory fared even worse, with failures in Brazil, Guatemala, Peru, Venezuela, and Colombia in

${ }^{42}$ O’Neill, Insurgency \& Terrorism, 56-60.

${ }^{43}$ Ian Beckett and John Pimlott, Counter Insurgency: Lessons from History (South Yorkshire, UK: Pen and Sword Military, 2011), 124.

${ }^{44}$ Guevara, Guerrilla Warfare, 7; Ernesto Guevara, "Message to the Tricontinental,” 16 April 1967, Che Guevara Internet Archive. Accessed 4 January 2015. https://www.marxists .org/archive/guevara/works.htm.

${ }^{45}$ Metz and Millen, Insurgency and Counterinsurgency in the 21st Century, 8; Boot, Invisible Armies, 449.

${ }^{46}$ Jenkins, The Five Stages of Urban Guerrilla Warfare, 1-4.

${ }^{47}$ Beckett, Modern Insurgencies and Counter-Insurgencies, 86; Anthony J. Joes, Resisting Rebellion: The History and Politics of Counterinsurgency (Lexington: University Press of Kentucky, 2004), 209-217. 
the mid-1960s alone. ${ }^{48}$ The capture and execution of Che in 1967 during his failed attempt to generate an insurgency using his theory in Bolivia prompted a general re-evaluation of rural guerrilla warfare theory. This re-evaluation gave rise to a significant evolution in guerrilla warfare; the development of urban guerrilla theory. ${ }^{49}$

\section{Guillén’s Urban Guerrilla Theory}

Guillén recognized two significant conditions present in many Latin American states that were different from the conditions that drove the development of the dominant rural theories. First, the incumbent regimes of Latin America had adapted to rural insurgencies and adjusted their counter insurgency strategies to become increasingly effective. Guillén writes, "helicopters, napalm, the $57 \mathrm{~mm}$ and $75 \mathrm{~mm}$ recoilless rifles, contradict many of the classical guerrilla theses concerning revolutionary war." ${ }^{50}$ He highlights US military assistance programs and training provided by "green berets" in Panama to emphasize the need for a change in insurgency strategies. ${ }^{51}$

Second, and most importantly, Guillén recognized that the populations of Latin America were rapidly growing and shifting from the rural areas to the cities. He states, "the economic crisis and the unrestricted growth of the population are leading toward a great social upheaval."52 Guillén argues that capitalism creates economic crisis by centralizing and accumulating wealth in

${ }^{48}$ James Kohl and John Litt, Urban Guerrilla Warfare in Latin America (Cambridge, MA: MIT Press, 1974), 6-7; Robert Moss, The War for the Cities (New York: Coward, McCann \& Geohegan, 1972), 148.

${ }^{49}$ Charles A. Russell, James A. Miller, and Robert E. Hildner, "The Urban Guerrilla in Latin America: A Select Bibliography,” Latin American Research Review 9, no. 1 (Spring 1974): 37-38.

${ }^{50}$ Guillén, Philosophy of the Urban Guerrilla, 233.

${ }^{51}$ Ibid., 281-282.

52 Ibid., 231. 
the cities, which draws the population from the countryside. Understanding his neo-Marxist worldview, he believed that capitalism enabled the gradual monopolization of enterprises, placing wealth and political power in the hands of few. ${ }^{53}$ Guillén believed that capitalist driven urbanization coupled with large population growth would create the motivation and epicenter of future insurgencies.

Guillén recognized that Mao and Che did not anticipate increased urbanization and the rising importance of the city and that the improved counter insurgency strategies were specifically designed to counter their theories, which contributed to the failure of many rural insurgencies. The recognition of these two factors prompted Guillén to develop an evolved theory for guerrilla warfare. His theory can be broken down into four principles: primacy of politics, requirement for necessary conditions, urban and rural integration, and a phased and protracted approach.

Primacy of Politics

Guillén understood the primacy of politics and the need to build a popular base of support. Guillén writes “the strategy of revolutionary war is essentially political: if it does not begin with a broad front of liberation, the guerrillas will lose the war strategically, regardless of tactical successes, from failure to obtain the support of the great mass of the population of an underdeveloped country." ${ }^{54}$ Countering the foquismo theory, Guillén subordinates military objectives to political goals writing, "the fundamental strategic objective is not space. The positive force is the will of the people.”55

\footnotetext{
${ }^{53}$ Guillén, Philosophy of the Urban Guerrilla, 236-237.

${ }^{54}$ Ibid., 253.

${ }^{55}$ Ibid., 242.
} 
Guillén argues that 80 percent of the population is required to defeat the incumbent regime, especially those with external support from the United States. ${ }^{56}$ In order to attract the widest possible base, Guillén argues that "guerrilla politics must not be sectarian, dogmatic or intolerant, but rather flexible in a new style freed from sematic 'isms,' operating politically in the name of the general interest in order to win support from the entire oppressed population.”57 Guillén believes the "principal preoccupation” of the insurgent should be the political campaign to win the population. ${ }^{58}$ To reinforce his point, Guillén highlights Che’s failure to develop a popular base of support in Bolivia that resulted in the destruction of the guerrilla foco and his execution in 1967. ${ }^{59}$

Guillén is careful in advocating the employment of violence, emphasizing that violence should always be directed toward political ends. He advocates the use of terrorism, in conjunction with other means of resistance, but stresses the need for restraint; always focused on winning and maintaining the support of the population. Emphasizing the psychological and emotional components of revolution, Guillén states that "to kill an ordinary soldier in reprisal for the assassination of a guerrilla is to descend to the same political level as a reactionary army. Far better to create a martyr and thereby attract mass sympathy than to lose or neutralize popular support by senseless killings without an evident political goal. A popular army that resorts to unnecessary violence that is not a symbol of justice, equity, liberty and security, cannot win popular support in the struggle against a dehumanized tyranny." 60

\footnotetext{
${ }^{56}$ Guillén, Philosophy of the Urban Guerrilla, 253.

${ }^{57}$ Ibid., 284.

${ }^{58}$ Ibid., 261.

${ }^{59}$ Ibid., 257.

${ }^{60}$ Ibid., 266.
} 


\section{Conditions Must Exist}

Guillén writes that a "historical occasion” must exist in order for any insurgency to achieve strategic success. Thus, "a revolution in a given country or region can only be made under particular historical and political conditions in which the ruling class has lost prestige." ${ }^{61} \mathrm{~A}$ historical occasion places political, economic, social, psychological, and morale hardships on the population, making it receptive to the idea of armed insurrection. Guillén notes the conditions created by the First World War on the Russian population and the Japanese invasion of China before the Second World War as examples of historical occasion. ${ }^{62}$ He believed the growth and urbanization of the population, coupled with the sever inequities of capitalism would create the favorable conditions for insurgency in Latin America. ${ }^{63}$

Cognizant of recent revolutionary failures, Guillén warns against initiating an insurgency in the absence of a historical occasion. Indeed, "to launch a guerrilla war in the form of an insurrectional foco in countries that enjoy certain democratic liberties and before an economic crisis reduces the relative level of life, is to run a strategical risk unfavorable to the guerrillas.”64 Guillén cites the Tupamaros’ continued use of political violence after successful Uruguayan national elections as an example. The Tupamaros did not wait for the new Uruguayan government to lose the trust of the population. The population passively accepted the government's heavy-handed counter insurgency operations that decimated the ranks of the Tupamaros; ultimately resulting in the destruction of organization. ${ }^{65}$

\footnotetext{
${ }^{61}$ Guillén, Philosophy of the Urban Guerrilla, 254.

62 Ibid., 255.

${ }^{63}$ Ibid., 231.

${ }^{64}$ Ibid., 291.

${ }^{65}$ Ibid., 275-276.
} 
Urban/Rural Mix

Abraham Guillén advocates a mixed urban and rural approach. To understand his theory as purely urban based would be inaccurate. Guillén’s emphasis on urban guerrilla warfare is stressed to counter the dominant theories that arose during the golden age of insurgency. His theory challenged the most prevalent guerrilla warfare theories, including Mao’s protracted popular war and Che's foquismo theory.

Guillén describes the state as a system of production with laws of population and social division of labor. Guillén believes that wherever capital accumulates, the population is drawn and bound to wage-labor, the law of population. ${ }^{66}$ In Latin America, as elsewhere, capital accumulates in the city, making it the center of gravity for the incumbent regime. ${ }^{67}$ The law of social division of labor refers to the relationship between the city and countryside, in which the city manufactures goods that generate capital, as the countryside provides the raw materials, such as food and natural resources, which sustain the city and enable production. While the countryside can exist without the city, the city as the point of industry cannot exist without the countryside. ${ }^{68}$ Ultimately, the government depends on the accumulation of wealth in the cities and must sustain the system of production.

Surveying this construction, Guillén’s theory of guerrilla warfare seeks to exploit these two laws, requiring both urban and rural efforts. According to the Spaniard, the urban guerrilla mobilizes through political activity the urban population alienated by the effects of capitalism in order to disrupt the system of production at the point of industry, the government's center of gravity. Meanwhile, the rural guerrilla provides a supporting but critical effort by attacking the flow of materials into the city, further disrupting the system of production. Faced by these threats,

\footnotetext{
${ }^{66}$ Guillén, Philosophy of the Urban Guerrilla, 236-237.

${ }^{67}$ Ibid., 285.

${ }^{68}$ Ibid., 238-239.
} 
the government is forced to respond to both efforts, pulling its forces beyond their capability. ${ }^{69}$ Linking urban and rural insurgencies into a coherent whole, Guillén suggests “not even in those countries with a high percentage of urban population is an effective strategy possible without including the countryside. Cooperation between the laborer and peasant is essential to the revolution." ${ }^{70}$

Protracted and Phased

Influenced by Mao Tse-tung, Guillén states that revolutionary war should be protracted and phased. He writes:

In a war of liberation the final victory is not decided by arms, as in imperialist wars. In revolutionary war that side wins which endures longest: morally, politically, and economically. In the old strategy the factors making for victory were firepower and the number of combatants; in revolutionary war, if one knows how to employ strategically the factors of time and space with the support of the population, the side that knows how to or can endure the longest will ultimately win. A praetorian army which oppresses and self colonizes its own people will never achieve victory but rather the most definitive and crushing defeat, that is, should it be forced to engage in small battles, compelled to waste away and to become demoralized by the time factor, and forced to strike in the void by the guerrillas rational and strategic employment of the factor of space. ${ }^{71}$

Assuming a disadvantage in force, Guillén envisions a strategy “as Fabius did against Hannibal” that stresses avoiding decisive conflict by trading space for time to build strength and wear down the adversary. ${ }^{72}$

To illustrate how the insurgency should be conducted in time and space, Guillén describes three phases. In the first phase, Guillén assumes the guerrillas are at a disadvantage to the incumbent in factors of force, preventing the guerrillas from being able to seize and retain

\footnotetext{
${ }^{69}$ Guillén, Philosophy of the Urban Guerrilla, 239.

${ }^{70}$ Ibid.

${ }^{71}$ Ibid., 233.

72 Ibid., 280.
} 
space. In this phase, space is ceded to avoid being encircled and destroyed by government forces. Political organization is the primary driver of operations. In the second phase, Guillén assumes that the guerrillas have generated popular support and have grown in size, but are still disadvantaged in factors of force. During the second phase, guerrillas attempt to pull government forces beyond their culminating point by creating security dilemmas in multiple urban and rural areas. The primary purpose during this phase is to wear down the government forces, while continuing to politically organize. In the third phase, Guillén assumes the guerrillas have achieved parity with the incumbent in factors of force and has transformed into a conventional army. During this phase, the army of liberation seizes and retains space, which he argues is necessary for final victory, even if the government and security forces collapse in an earlier phase. $^{73}$

Abraham Guillén shared his theory for urban guerrilla warfare by publishing three works, Theory of Violence in 1965, Strategy of the Urban Guerrilla in 1966, and Challenge to the Pentagon in $1969 .{ }^{74}$ Abraham Guillén’s theory became very influential within Latin America from the mid-1960s to the early 1970s. His writings, most notably the Strategy of the Urban Guerrilla, also influenced guerrillas in the United States, Europe, Japan, and the Middle East. ${ }^{75}$ For example, Guillén’s theory on guerrilla warfare influenced the Provisional Irish Republican Army's (PIRA) strategy in Northern Ireland during the 1970s. Through the 1960s, the PIRA attempted to employ a rural strategy influenced by the protracted popular war and foquismo theories. After experiencing political and military failure, the PIRA adjusted to a more urban based strategy espoused by Guillén. ${ }^{76}$ Unprepared for this type of warfare, the UK’s overly

\footnotetext{
${ }^{73}$ Guillén, Philosophy of the Urban Guerrilla, 286-287.

${ }^{74}$ Hodges, Philosophy of the Urban Guerrilla, 8.

${ }^{75}$ Laqueur, Guerrilla Warfare, 320-321.

${ }^{76}$ Hoyt, “Adapting to a Changing Environment,” 50.
} 
militarized and heavy-handed counter-insurgency strategy intensified the conditions that fueled the insurgency. ${ }^{77}$

A Relevant Theory for Guerrilla Warfare: Analysis of Guillén’s Theory

Despite the influence of Guillén’s theory, urban guerrilla movements have been discredited as flawed concepts. Bard O’Neill stated, “with the exception of South Yemen in 1967, the urban-warfare strategy has been ineffective.”78 Anthony J. Joes concludes, "nowhere in the twentieth century has urban guerrilla warfare achieved an unambiguous success."79 Often, the failure of the urban strategy in practice has been transferred to the theorists. Max Boot states, “Marighella was just as unsuccessful as Guevara. His urban foco disappeared as fast as Che’s rural foco in Bolivia.” ${ }^{80}$ To determine the efficacy of Abraham Guillén’s theory of urban guerrilla warfare, his theory will be analyzed against five consistent trends that correlate with successful insurgencies: availability of sanctuary, restricted use of terrorism, rural based, external support, and broad coalition formation. Analyzing Guillén’s theory utilizing the five trends associated with successful insurgencies, his theory demonstrates more strengths than weaknesses. Guillén’s theoretical strengths include: advocating an urban/rural hybrid that accounts for demographics and environment, restricted employment of terrorism, and emphasis on coalition formation. Guillén’s theoretical weaknesses include little discussion on sanctuary and the complete absence

${ }^{77}$ Rasmussen, The Military Role in Internal Defense and Security, 17-33; LaFree, "Efficacy of Counterterrorism Approaches."

${ }^{78}$ O’Neill, Insurgency and Terrorism, 62.

${ }^{79}$ Joes, Urban Guerrilla Warfare, 157.

${ }^{80}$ Carlos Marighella developed a theory of urban guerrilla warfare in the late 1960s, which stressed the importance of an urban insurgency to compliment the rural foco. Boot, Invisible Armies, 447-448. 
of any discussion on the necessity of external support. Recognizing theoretical weaknesses, Guillén’s theory of urban guerrilla warfare still provides a valuable blueprint for executing an effective insurgency.

Framework for Analysis

The framework for analysis was developed by combining the analysis of two works. In a RAND report, How Insurgencies End, Ben Connable and Martin C. Libicki examined 89 insurgencies conducted after 1945 to identify several consistent trends that correlate with how insurgencies end. ${ }^{81}$ Although their research was geared towards developing more effective counterinsurgency strategies, many of their findings are useful in analyzing the efficacy of insurgent strategies. Some trends identified by Connable and Libicki were not utilized because they were not conclusive or relevant for this study. For example, Connable and Libicki found that protracted struggles tend to benefit counterinsurgents, against popular convention, but admit that the data is not as conclusive as in some of the other trends. ${ }^{82}$ Misagh Parsa's findings from comparative analysis of revolutions in Iran, Nicaragua, and the Philippines in, States, Ideologies, and Social Revolutions, is also utilized in the framework for analysis. He finds close correlation with the ability to establish broad coalitions and successful revolution. ${ }^{83}$ Utilizing the findings of these two works, five factors that contribute to successful insurgencies can be combined and used to determine a more unbiased value of Abraham Guillén’s theory: availability of sanctuary, restricted use of terrorism, rural based, external support, and broad coalition formation.

\footnotetext{
${ }^{81}$ Connable and Libicki, How Insurgencies End, 2-3.

${ }^{82}$ Ibid., 29.

${ }^{83}$ Parsa, States, Ideologies, and Social Revolutions, 239.
} 
Trend of Rural Success

Rural insurgencies are more successful than urban insurgencies. Connable and Libicki found that in countries with less than 40 percent urbanization, the insurgent won 75 percent of the time. However, as the level of urbanization increases, there is a significant shift in the success of insurgencies. In countries with more than 70 percent urbanization, the insurgent loses 75 percent of the time. ${ }^{84}$ This has been attributed to the advantages held by government forces in urban areas, such as intelligence collection and ability to move and mass against insurgents. Anthony J. Joes states, "while the state is often present in rural areas, it will be heavily present in cities," making urban insurgents more vulnerable to detection and destruction. ${ }^{85}$ When insurgents operate more covertly to mitigate security force advantages, they cut themselves off from the population and have trouble building popular support across the disparate groups within a city. ${ }^{86}$ Joes states that the Tupamaros failure to build a mass base of popular support, a major contributing factor to their strategic failure, can be partially attributed to their covert nature. ${ }^{87}$

The correlation of rural success and urban failure provides strength to Guillén’s theory for several reasons. First, Guillén does not advocate a purely urban strategy. He does state that in countries with high urbanization, without an urban insurgency, revolution cannot succeed. ${ }^{88}$ However, he stresses the importance of unifying the urban movement with a rural movement stating, "this war must not be fought only in the countryside nor must it be fought only in the city. Each must compliment the other." ${ }^{89}$ His emphasis on urban operations is stressed to counter the

\footnotetext{
${ }^{84}$ Connable and Libicki, How Insurgencies End, 88.

85 Joes, Urban Guerrilla Warfare, 86-87.

${ }^{86}$ Connable and Libicki, How Insurgencies End, 92-93.

${ }^{87}$ Joes, Urban Guerrilla Warfare, 87-88.

${ }^{88}$ Guillén, Philosophy of the Urban Guerrilla, 237-239.

${ }^{89}$ Ibid., 244.
} 
dominate theories of that era, including Mao's protracted popular revolution and Che's foquismo theory, which were purely rural based theories.

Second, Guillén specifically emphasizes operating in urban areas that avoid the strengths of the government. Above all else, Guillén stresses the two laws for urban guerrillas to live by: mobility and secrecy. ${ }^{90}$ He states, "in order to avoid encirclement and annihilation through house to house searches, the guerrillas can best survive not by establishing fixed urban bases, but by living apart and fighting together." ${ }^{91}$ He encourages shifting from hierarchical organization to a decentralized cellular structure to enable dispersed operations and reduce communications. ${ }^{92} \mathrm{He}$ also places a primacy on avoiding any permanent facilities, such as safe houses, supply depots, or headquarters, as these are susceptible to discovery by government forces. Lastly, Guillén specifically addresses the difficulty of building mass bases in urban areas and stresses the importance of building broad coalitions, which is covered in the following section.

\section{Broad Coalitions}

Insurgencies are more successful when insurgent leadership can build broad coalitions. Providing a comparative analysis on Iran, Nicaragua, and Philippines, Misagh Parsa argues that broad coalitions increase the chances of insurgent success because they deny popular support to the incumbent, disrupt the armed forces, enable large scale disruptive activity against the incumbent, and can build popular support for armed violence against the government. ${ }^{93}$ All three case studies experienced periods of political turmoil in which government opposition could not generate revolution because of the absence of broad coalitions. Once broad coalitions were

\footnotetext{
${ }^{90}$ Guillén, Philosophy of the Urban Guerrilla, 264.

${ }^{91}$ Ibid., 264.

92 Ibid., 267-268.

${ }^{93}$ Parsa, States, Ideologies, and Social Revolutions, 239.
} 
formed, the incumbent regimes in Iran and Nicaragua were removed from power. ${ }^{94}$ However, in the Philippines case study leftist radicals deterred the capitalist classes from joining the coalition, preventing the collapse of the regime and drawing out the conflict in stalemate. Regime change only occurred after the United States pressured the regime to step down. ${ }^{95}$ Broad coalitions included elements that cut across all levels of society, regardless of class. Interestingly, and most significantly for this research, capitalists tend to be the most difficult to include in coalitions because of their dependence on the market. ${ }^{96}$

Building broad coalitions is one of Guillén’s most significant theoretical strengths. Guillén is one of the few guerrilla theorists who addresses the importance of building broad coalitions stating "if [revolutionary war] does not begin with a broad front of liberation, the guerrillas will lose the war strategically, regardless of tactical successes, from failure to obtain the

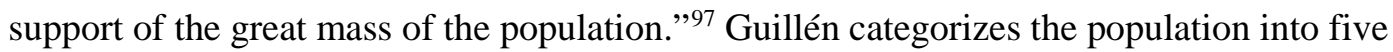
classes: the workers, peasants, proletarianized middle class, native bourgeoisie, and landed oligarchy.${ }^{98}$ Like other insurgent theorists, he includes the peasants, workers, and students as a base for a broad front. However, unlike the other theorists, particularly those inspired by Marxism, Guillén stresses the inclusion of segments of the bourgeoisie, Parsa’s capitalists, that are reliant on the market but oppose foreign competition. ${ }^{99}$ Guillén goes so far as to say that nationalism should be the ideological rallying call, as opposed to more radical socialist views

\footnotetext{
${ }^{94}$ Parsa, States, Ideologies, and Social Revolutions, 240-241.

${ }^{95}$ Ibid., 262-275.

${ }^{96}$ Ibid., 197.

${ }^{97}$ Guillén, Philosophy of the Urban Guerrilla, 253.

${ }^{98}$ Ibid., 252.

${ }^{99}$ Ibid., 252-253.
} 
often held by insurgents of that time. ${ }^{100}$ The necessity of a broad coalition, including elements of the capitalist class, is a consistent theme throughout Problems of Revolutionary Strategy and Challenge to the Pentagon.

\section{Restricted Use of Terrorism}

Connable and Libicki found that "broad terror campaigns by insurgents correlate with insurgent defeat, but selective terror attacks that do not kill innocent civilians correlate with marked insurgent advantage.”101 This is particularly notable among urban insurgencies. An explanation for this is that populations exposed to indiscriminate violence directed towards civilians eroded support for the insurgency, and can build support for intrusive and heavy handed methods employed by counterinsurgents. Connable and Libicki argue that it was Sendero Luminoso's indiscriminate use of terror attacks that eroded the support of the Peruvian population and encouraged the formation of right wing paramilitary groups; a significant contributor to the Sendero Luminoso's defeat. ${ }^{102}$

Restricted use of terrorism can be considered a theoretical strength of Guillén’s. Guillén believes that terrorism is an important element in insurgency. ${ }^{103}$ He states that terrorism must be synchronized with other tactics in a wider strategy that pursues political effects. ${ }^{104}$ More importantly, he writes, "it is impolitic to make a show of their [the government and security

${ }^{100}$ Guillén, Philosophy of the Urban Guerrilla, 259.

${ }^{101}$ Connable and Libicki, How Insurgencies End, xvii.

102 Sendero Luminoso (Shining Path) was a Maoist-based guerrilla movement that attempted to overthrow the government of Peru with a communist regime in the 1980s. The Shining Path is infamous known for its excessive employment of violence and brutality. Connable and Libicki, How Insurgencies End, 104-106.

${ }^{103}$ Guillén, Philosophy of the Urban Guerrilla, 290, 301.

${ }^{104}$ Ibid., 301. 
forces] crimes for the purpose of creating a climate of terror, insecurity, and disregard for basic human rights. A popular army that resorts to unnecessary violence that is not a symbol of justice, equity, liberty and security, cannot win popular support in the struggle against a dehumanized tyranny." 105 Throughout his writing, Guillén consistently reinforces the need for the insurgency to control violence in order to enhance and sustain legitimacy in the eyes of the population.

Guillén criticizes the Tupamaros for their failure to restrict the use of terrorism. Initially, in accordance with his theory, the Tupamaros restricted their use of terrorism and were perceived as legitimate by the population. This is partly because of their ingenious use of political violence. Although they conducted many kidnappings and bank robberies, they did not utilize violence against civilians. During a bank robbery, a Tupamaro performed first aid on a civilian who fainted. Kidnapping targets were typically members of the government or security forces accused of corruption or incompetence. ${ }^{106}$ They were released unharmed after damning confessions were taped and broadcast to the population. This fostered a positive image for the organization and fueled their initial popularity. Their use of assassinations was restricted to those personnel within the security forces that employed torture or assassination. For a variety of reasons by 1968 , the Tupamaros began to utilize terror tactics more indiscriminately. Guillén specifically criticizes the kidnapping and execution of Dan Mitrione, a US advisor to Uruguay. The act, he claims, was politically void, turned the media against the Tupamaros, and branded the organization as assassins. ${ }^{107}$ Guillén warns insurgents to avoid violent actions against the population that may bring about some tactical success, as these incidents can have disastrous strategic consequences.

${ }^{105}$ Guillén, Philosophy of the Urban Guerrilla, 266.

${ }^{106}$ Kohl and Litt, Urban Guerrilla Warfare in Latin America, 173.

${ }^{107}$ Guillén, Philosophy of the Urban Guerrilla, 270. 
Availability of Sanctuary

Connable and Libicki determined that "sanctuary- voluntary, involuntary, external or internal- is a fundamental provision for the insurgent,” and that there is a strong correlation between a lack of sanctuary and insurgent defeat. ${ }^{108}$ Of the insurgencies analyzed, only three of 22 insurgencies that did not have sanctuary were successful. One of the successful insurgencies was the Cuban Revolution. Fidel Castro and his rural foco did not have access to external sanctuary and were largely trapped within the Sierra Maestra, a mountain range in southeastern Cuba. Castro’s success, despite a lack of sanctuary, was only possible because the Batiste regime was so militarily ineffective. ${ }^{109}$ Connable and Libicki also determined that every urban insurgency without sanctuary failed to achieve all of their objectives. ${ }^{110}$ This is largely attributed to the fact that groups without sanctuary to base headquarters, supply depots, and training areas are severely handicapped in their ability to transition beyond the small scale guerrilla warfare phase. ${ }^{111}$ Interestingly, Connable and Libicki point to Guillén’s writing in Problems of Revolutionary Strategy, highlighting his aversion to establishing sanctuary. ${ }^{112}$

Availability of sanctuary should be considered a theoretical weakness in Guillén’s theory. On this topic, Guillén tends to contradict himself. Connable and Libicki are correct in that Guillén’s theory advises against the establishment of sanctuary in the early phases of insurgency. In Problems of Revolutionary Strategy, Guillén writes, “strategically, a very small guerrilla army must operate in view of bringing about a mass insurrection without engaging the popular forces in an initial battle, without fastening itself to a given space, without creating fixed mountain

\footnotetext{
${ }^{108}$ Connable and Libicki, How Insurgencies End, xvii, 42.

${ }^{109}$ O’Neill, Insurgency and Terrorism, 146.

${ }^{110}$ Connable and Libicki, How Insurgencies End, 38.

${ }^{111}$ O’Neill, Insurgency and Terrorism, 147-148.

${ }^{112}$ Connable and Libicki, How Insurgencies End, 38.
} 
encampments." ${ }^{113}$ He consistently emphasizes mobility and warns against becoming attached to terrain that presents an area the government can mass against with sophisticated military weapons such as aircraft and artillery. ${ }^{114}$ However, in Challenge to the Pentagon, Guillén details another view in which sanctuary has value. He lays out the strategic phasing as building liberated zones as soon as the insurgency is strong enough to maintain them; in the second and third phase of insurgency. ${ }^{115}$ Guillén goes on to state:

If a country oppressed by tyranny has high-mountain and forest zones, however, there is a double possibility of attacking the enemy in the cities and mountains. Under these conditions and in order that the city may not become an immense prison for recognized revolutionaries, those whose names and photos have been given publicity should take to the mountains and carry on the struggle in liberated or semi liberated terrain, which would constitute for them a kind of liberation. ${ }^{116}$

Guillén clearly sees value in the establishment of sanctuary in the rural areas, not just for rural operations, but in support of urban operations, where establishing sanctuary is dangerous. However, writing on the topic of sanctuary is sparse and Guillén contradicts himself on its importance.

External Support

Connable and Libicki determined "the relative value of external support over time is a critical factor in shaping end state, especially compared to other correlative factors.” ${ }^{117}$ External support tends to be a critical aspect of successful insurgencies. Connable and Libicki find that insurgencies with external support from a state or non-state actors have roughly a 50 percent

${ }^{113}$ Connable and Libicki, How Insurgencies End, 38.

${ }^{114}$ Guillén, Philosophy of the Urban Guerrilla, 264.

${ }^{115}$ Guillén, Philosophy of the Urban Guerrilla, 286.

116 Ibid., 292-293.

${ }^{117}$ Connable and Libicki, How Insurgencies End, 64. 
success rate, which drops precipitously if withdrawn. Insurgencies without external support were successful only three of 18 times. ${ }^{118}$ External support includes direct military intervention, logistics, transportation, medical, training, and sanctuary. O’Neill states, regardless of the level of popular support, insurgents most often require some outside assistance to combat government military forces, especially when facing defeat. ${ }^{119}$

Guillén’s lack of discussion on external support can be considered a theoretical weakness. Guillén does not discuss support from external states, nor does he specifically address material, financial, training, personnel, or sanctuary cooperation between different organizations in varied countries. Discussions on support are limited to internal support from the relevant population. There is evidence that Guillén encouraged collaboration between guerrilla organizations from different countries, however, there is no indication whether mutual support went beyond temporary operational collaboration.

Guillén clearly views the urban effort as requiring less support, and encourages selfsufficiency. Showing recognition of external support as an important factor, Guillén does state that insurgencies “must be made without the assistance of Russia," as he believed the era of détente diminished Russia’s interest in supporting revolution. ${ }^{120}$ Guillén also discusses the development of Latin American multinational organizations and unified command that unites the insurgent movements of South and Central America under a single strategy. ${ }^{121}$ However, he does not detail the necessity of material support from one group to another as much as guiding all organizations toward a common goal.

\footnotetext{
${ }^{118}$ Connable and Libicki, How Insurgencies End, 62.

${ }^{119}$ O’Neill, Insurgency and Terrorism, 147-148.

${ }^{120}$ Guillén, Philosophy of the Urban Guerrilla, 300-301.

${ }^{121}$ Ibid., 230-231.
} 
Guillén’s theory of urban guerrilla warfare provides a relevant blueprint for insurgency in the contemporary operating environment. This is validated by analyzing Guillén’s theory through a framework built on trends that are closely correlated with successful insurgencies. Guillén may not be the Mao of the city; he provides contradictory guidance on establishing sanctuary and there is a deficiency of discussion on the importance of external support. However, his theory is strong on encouraging the synchronization of urban and rural efforts, restricted use of terrorism, and the formation of broad coalitions.

There is evidence of a resurgence in the application of urban guerrilla in contemporary insurgencies. After sustaining major military losses in the late 1990s and early 2000s, the FARC began seeking external assistance to improve their ability to conduct insurgency operations. The FARC, historically a rural-based insurgency, received training from the PIRA in urban guerrilla warfare between 2002 and 2004. ${ }^{122}$ Beginning in 2005, the FARC began a renewed insurgency campaign with increasingly effective operations within urban areas; a new trend that alarmed Colombian security forces. ${ }^{123}$ The FARC’s connection to Guillén is indirect; however, the training provided by the PIRA was as much influenced by Guillén's theory as the theories of Antoine-Henri Jomini and Carl von Clausewitz influence US Army doctrine. Interestingly, experts believe that the PIRA, as well as other insurgent organizations, has been sharing its knowledge with other organizations for decades. ${ }^{124}$

${ }^{122}$ Cragin et al., Sharing the Dragon's Teeth, 71-73.

123 “Fuerzas Armadas Revolucionarias de Colombia (FARC),” Jane’s World Insurgency and Terrorism Database, 7 March 2014. Accessed 17 November 2014. https://janes.ihs.com /CustomPages/Janes/DisplayPage.aspx?DocType=Reference\&ItemId=+++1320752.

${ }^{124}$ Forest, “Knowledge Transfer and Shared Learning among Armed Groups,” 272. 


\section{Guillén’s Theory and Future Warfare}

Abraham Guillén’s theory for urban guerrilla warfare will be increasingly relevant in the future. US Army Field Manual (FM) 3-24, Insurgencies and Countering Insurgencies, details several global trends that "may provoke more insurgencies in the future," including increases in urbanization, globalization, and number of failed or failing states. ${ }^{125}$ Understanding the strengths and weaknesses of Guillén’s theory, these global trends create an environment in which Guillén’s theory becomes increasingly relevant. Rapid urbanization and population growth in underdeveloped states increases the likelihood of conflict in cities, fostering the historical occasion necessary for insurgency. Failed or failing states will be unable to provide governance, services, and security, creating ungoverned spaces for insurgents to exploit and operate in; a situation that mitigates Guillén’s shortfall in sanctuary. The impacts of globalization, more specifically advances in communications, will enable urban guerrillas to communicate with wide audiences and among each other while remaining anonymous to counterinsurgents; overriding criticisms of Guillén’s failure to reconcile how urban guerrillas can maintain contact with the population while operating covertly. Considering the impacts of these trends, Abraham Guillén’s theory of urban guerrilla warfare provides a relevant blueprint for guerrilla warfare in the future.

\section{Urbanization}

The rapid growth and urbanization of the world's population is not new; Guillén recognized this trend and designed his theory of action to exploit it. In 1995, Jennifer Morrison Taw and Bruce Hoffman warned of a continuation of the trends that gave rise to Guillén’s theory, stating, "a demographic upheaval of seismic proportions is today transforming almost the entire developing world from a predominantly rural society to an urban one.” ${ }^{126}$ More recent research

${ }^{125}$ Field Manual 3-24: Insurgencies and Countering Insurgencies (Washington, DC: Department of the Army, 2014), 2.1-2.2. 
predicts an increase in global population from the roughly 7.1 billion that exist today to 9.1 billion by 2050, with approximately 75 percent living in urban areas. ${ }^{127}$ Over 90 percent of the population growth in cities is expected to occur in underdeveloped states. ${ }^{128}$

Peter Engelke, a Senior Fellow with the Atlantic Council’s Strategic Foresight Initiative, and Magnus Nordenman, deputy director of the Brent Scrowcroft Center, highlight that "slum formation has been a central characteristic of rapid urbanization in the global South and is expected to continue well into the future." ${ }^{229}$ In most cases, the increase in population in cities is not supported by economic opportunity, and large portions of the population are unable to find employment. Abraham Guillén recognized this trend in the early 1960s writing, "the economic crisis and the unrestricted growth of the population are leading toward a great social upheaval.” ${ }^{130}$ The social upheaval will provide the historical occasion for urban guerrillas to exploit. Rapid urbanization and population growth in underdeveloped states increases the likelihood of conflict in cities, fostering the historical occasion necessary for insurgency. This trend is particularly troublesome when you synthesize it with the number of failed and failing states already operating beyond their capacity.

126 Taw and Hoffman, “The Urbanization of Insurgency,” 68.

${ }^{127}$ Kilcullen, Out of the Mountains, 28-29.

${ }^{128}$ Wendell Cox, "World Urban Areas Population and Density: A 2012 Update," in New Geography, 3 May 2012. Accessed 11 February 2015. http://www.newgeography.com/content /002808-world-urban-areas-population-and-density-a-2012-update.

${ }^{129}$ Peter Engelke and Magnus Nordenman, "Megacity Slums and Urban Insecurity,” Atlantic Council, 30 January 2015. Accessed 11 February 2015. http://www.atlanticcouncil.org/ blogs/futuresource/megacity-slums-and-urban-insecurity.

${ }^{130}$ Guillén, Philosophy of the Urban Guerrilla, 231. 
Failed and Failing States

According to United Nations (UN) 2014 World Urbanization Prospects report, “Africa...is expected to be the fastest urbanizing region from 2020 to 2050.”131 A 2008 UN Habitat report estimated over 60 percent of the urban population in Sub-Saharan Africa lives in slums, without access to essential services, critical infrastructure, governance, and security. ${ }^{132}$ In the Fund for Peace’s 2014 Fragile State Index, the top five states evaluated to be at highest risk of becoming weak or failing states are located in Africa. Of the top 34 states at most risk, 21 are African states. ${ }^{133}$ Many of the fragile African states already struggling to provide good governance, essential services, and internal security will be experiencing the largest population growth and urbanization over the next 25 years. Although the statistics are not as bleak, several states in Asia and South America will face similar challenges.

The impact of rapid population growth and urbanization coupled with poor governance and overextended security forces creates ungoverned spaces from which guerrillas can operate relatively freely. The United States is already concerned with ungoverned space in Nigeria, Mali, Somalia, Libya, Algeria, and Sudan, which currently host several violent extremist organizations that threaten regional stability. ${ }^{134}$ With fragile states unable or unwilling to cope with the services and security demands created by population growth in cities, ungoverned spaces will provide internal sanctuary within the city; mitigating a theoretical weakness of Guillén’s theory for urban guerrilla warfare.

${ }^{131}$ United Nations Department of Economics and Social Affairs, Population Division, World Urbanization Prospects: The 2014 Revision (New York: United Nations, 2014), 9.

${ }^{132}$ Engelke and Nordenman, "Megacity Slums and Urban Insecurity.”

133 Nate Haken et al., Fragile State Index 2014 (Washington, DC: The Fund for Peace, 2014), 4-5.

${ }^{134}$ Robert Windrem, “US Aims to Root Out 'Ungoverned Spaces' as Hotbeds of Terrorism,” NBC News, 23 August 2014. Accessed 11 February 2015. http://www.nbcnews .com/news/investigations/u-s-aims-root-out-ungoverned-spaces-hotbeds-terrorism-n181941. 
Globalization

Globalization refers broadly to the increasingly interconnectedness of the global community. ${ }^{135}$ In no other area is this more pronounced than in the realm of communications. One of the most important instruments of any insurgent organization is its means of communication. As a relatively new technology, the internet and the tools it provides have dramatically increased the ability of insurgents to communicate not only to wide audiences, but also within themselves. The internet facilitates the distribution of propaganda to a global audience and recruitment from a global pool. It enables fund raising through donation as well as legitimate and criminal business enterprises. The internet provides access to a wealth of information useful in planning attacks, virtual classrooms to train new recruits, and an effective medium to coordinate operations. The global connectivity of the internet does all of the above in an unregulated, easily accessible, cheap environment that allows insurgents to remain anonymous. ${ }^{136}$ Guillén, and urban guerrillas in general, are criticized for not reconciling the need to operate covertly while conducting the political activities that, as Guillén states, are paramount to success. ${ }^{137}$ However, advances in communications will enable urban guerrillas to communicate with wide audiences and among each other while remaining anonymous; overriding criticisms of Guillén’s theory. Al Qaida’s ability to exploit the potential of the internet provides a good example. As Audrey Cronin states, "the burgeoning methods of communication and the rapid dissemination of Al Qaida's message of radicalization marks this movement as a new stage in the

${ }^{135}$ Querine H. Hanlon, “Globalization and the Transformation of Armed Groups,” in Armed Groups: Studies in National Security, Counterterrorism, and Counterinsurgency, 116.

${ }^{136}$ Brigitte L. Nacos, Mass Mediated Terrorism: The Central Role of the Media in Terrorism and Counterterrorism (New York: Rowman and Littlefield, 2007), 114-115; Hanlon, “Globalization and the Transformation of Armed Groups,” 116-120.

${ }^{137}$ Joes, Urban Guerrilla Warfare, 6-7, 158. 
evolution of terrorism." ${ }^{138}$ It is the capabilities provided by the internet that enables Al Qaida to continue to survive and conduct operations through a highly decentralized network under enormous pressure from increasingly effective counter-terror strategies. ${ }^{139}$ As the US Army anticipates future conflict, Abraham Guillén’s theory of urban guerrilla warfare becomes a useful tool in understanding how adversaries will organize and operate in an increasingly interconnected and urban world.

\section{Conclusion}

Abraham Guillén’s theory on urban guerilla warfare marked a significant evolution from popular theories on guerrilla warfare during the late 1960s. Rural based guerrilla warfare became the dominate theory guiding insurgency from the early 1940s through the mid-1960s. Rural strategies influenced by Mao Tse-tung’s protracted revolutionary warfare and Che Guevara’s foco theory were employed across South East Asia, Africa, and Latin America. However, by the late 1960s, a wave of unsuccessful insurgencies in Latin America and Africa brought the efficacy of the dominant rural guerilla theories into question. ${ }^{140}$

Guillén recognized two significant conditions present in many Latin American states that were different from the conditions that drove the development of the dominant rural theories. Counterinsurgents had adapted to rural guerrilla warfare and were employing increasingly effective strategies. More importantly, Guillén recognized that the populations of Latin America were rapidly growing and shifting from the rural areas to the cities. This prompted Guillén to

${ }^{138}$ Audrey K. Cronin, How Terrorism Ends: Understanding the Decline and Demise of Terrorist Campaigns (Princeton, NJ: Princeton University Press, 2009), 176.

${ }^{139}$ Richard Shultz, "Virtual Sanctuary Enables Global Jihad,” in Armed Groups: Studies in National Security, Counterterrorism, and Counterinsurgency, 431-441.

140 Jenkins, The Five Stages of Urban Guerrilla Warfare, 1-4. 
develop an evolved theory for guerrilla warfare that emphasized the primacy of politics, requirement for necessary conditions, urban and rural integration, and a protracted and phased approach. His theory became very influential within Latin America by the early 1970s. His writings, most notably the Strategy of the Urban Guerrilla, also influenced guerrillas in the United States, Europe, Japan, and the Middle East. ${ }^{141}$

There is general consensus among experts that urban guerrilla warfare is a flawed and irrelevant concept. O’Neill states, “with the exception of South Yemen in 1967, the urban-warfare strategy has been ineffective.”142 Joes concludes, "nowhere in the twentieth century has urban guerrilla warfare achieved an unambiguous success.” ${ }^{143}$ The experts are correct in their analysis of urban insurgencies; however, the failure of the urban strategy in practice has been unfairly transferred to the urban theorists.

Using five consistent trends that correlate with successful insurgencies, Guillén’s theory demonstrates more strengths that weaknesses. Guillén’s theoretical strengths include: advocating an urban/rural hybrid that accounts for demographics and environment, restricted employment of terrorism, and emphasis on coalition formation. Guillén’s theoretical weaknesses include little discussion on sanctuary and the complete absence of any discussion on the necessity of external support. Recognizing theoretical weaknesses, Guillén’s theory of urban guerrilla warfare still provides a valuable blueprint for executing an effective insurgency.

Abraham Guillén’s theory provides valuable insight into how future adversaries may organize, operate, and adapt in an increasingly complex environment US forces are likely to operate within in the future. The current trends of rapid population growth and urbanization in fragile states and the impact of modern communications are creating an environment in which

\footnotetext{
${ }^{141}$ Laqueur, Guerrilla Warfare, 320-321.

142 O’Neill, Insurgency and Terrorism, 62.

143 Joes, Urban Guerrilla Warfare, 157.
} 
urban guerrilla warfare is increasingly likely. These trends also foster the optimal conditions for Guillén’s theory, mitigating his theoretical weaknesses and enhancing his strengths. Guillén may not yet be the Mao of the city, but by the middle of this century his ideas may influence a new generation of guerrillas. 


\section{Bibliography}

Beckett, Ian and John Pimlott. Counter Insurgency: Lessons from History. South Yorkshire, UK: Pen and Sword Military, 2011.

Beckett, Ian F.W. Modern Insurgencies and Counter-Insurgencies: Guerrillas and their Opponents since 1750. New York: Routledge, 2001.

Boot, Max. Invisible Armies: An Epic History of Guerrilla Warfare from Ancient Time to the Present. New York: W.W. Norton, 2013.

Castro, Daniel, ed. Revolution and Revolutionaries: Guerrilla Movements in Latin America. Wilmington, DE: Scholarly Resources, 1999.

Childs, Matt D. “An Historical Critique of the Emergence and Evolution of Ernesto Guevara's Foco Theory.” Journal of Latin American Studies 27, no. 3 (October 1995): 593-624.

Connable, Ben and Martin C. Libicki. How Insurgencies End. Santa Monica, CA: RAND, 2010.

Cox, Wendell. “World Urban Areas Population and Density: A 2012 Update.” New Geography (May 2012). Accessed 11 February 2015. http://www.newgeography.com/content/ 002808-world-urban-areas-population-and-density-a-2012-update.

Cragin, Kim, Peter Chalk, Sara A. Daly, and Brian A. Jackson. Sharing the Dragon's Teeth: Terrorist Groups and the Exchange of New Technologies. Santa Monica, CA: RAND, 2007.

Cronin, Audrey K. How Terrorism Ends: Understanding the Decline and Demise of Terrorist Campaigns. Princeton, NJ: Princeton University Press, 2009.

Engelke, Peter and Magnus Nordenman. "Megacity Slums and Urban Insecurity.” Atlantic Council (January 2015). Accessed 11 February 2015. http://www.atlanticcouncil.org/ blogs/futuresource/megacity-slums-and-urban-insecurity.

Forest, James J. F. “Knowledge Transfer and Shared Learning among Armed Groups.” In Norwitz, 269-290.

“Fuerzas Armadas Revolucionarias de Colombia (FARC).” Jane’s World Insurgency and Terrorism Database (March 2014). Accessed 5 August 2015. https://janes.ihs.com/ CustomPages/Janes/DisplayPage.aspx?DocType=Reference\&ItemId=+++1320752.

Guevara, Ernesto. “General Principles of Guerrilla Warfare.” In Castro, 65-86.

. Guerrilla Warfare. New York: Monthly Review Press, 1961.

" "Message to the Tricontinental.” Che Guevara Internet Archive. (April 1967). Accessed 4 January 2015. https://www.marxists.org/archive/guevara/works.htm.

Guillén, Abraham. Philosophy of the Urban Guerrilla: The Revolutionary Writings of Abraham Guillén. Translated and edited by Donald C. Hodges. New York: William Morrow, 1973. 
__. “Urban Guerrilla Strategy.” In Laqueur, The Guerrilla Reader, 229-237.

Haken, Nate, J.J. Messner, Krista Hendry, Patricia Taft, Kendall Lawrence, Laura Brisard, and Felipe Umana. Fragile State Index 2014. Washington, DC: The Fund for Peace, 2014.

Hanlon, Querine H. “Globalization and the Transformation of Armed Groups.” In Norwitz, 115126.

Hennessy, Alistair. “The New Radicalism in Latin America.” Journal of Contemporary History 7, no. 1/2 (January-April 1972): 1-26.

Hoyt, Timothy D. "Adapting to a Changing Environment: The Irish Republican Army as an Armed Group.” In Norwitz, 47-60.

Jenkins, Brian Michael. An Urban Strategy for Guerrillas and Governments. Santa Monica, CA: RAND Corporation, 1975.

- The Five Stages of Urban Guerrilla Warfare: Challenges of the 1970s. Santa Monica, CA: RAND, 1971.

Joes, Anthony James. Resisting Rebellion: The History and Politics of Counterinsurgency. Lexington: University Press of Kentucky, 2004.

—. Urban Guerrilla Warfare. Lexington: University Press of Kentucky, 2007.

Johnson, Chalmers. “The Third Generation of Guerrilla Warfare.” Asian Survey 8, no. 6 (June 1968): 435-447.

Kilcullen, David. Out of the Mountains: The Coming Age of the Urban Guerrilla. New York: Oxford University Press, 2013.

Kohl, James and John Litt. Urban Guerrilla Warfare in Latin America. Cambridge, MA: MIT Press, 1974.

LaFree, Gary. "Efficacy of Counterterrorism Approaches: Examining Northern Ireland." National Consortium for the Study of Terrorism and Responses to Terrorism, University of Maryland (October 2006). Accessed 24 July 2014. http://www.start.umd.edu/sites/ default/files/files/publications/research_briefs/20061017_lafree.pdf.

Laqueur, Walter. Guerrilla Warfare: A Historical and Critical Study. New Brunswick, NJ: Transaction Publishers, 1998.

— Press, 1977.

Levine, Robert M. “Perspectives on the Mid-Vargas Years 1934-1937.” Journal of Interamerican Studies and World Affairs 22, no. 1 (February 1980): 57-80.

Mackinlay, John. Globalization and Insurgency. New York: Oxford University Press, 2002.

Marighella, Carlos. “Problems and Principles of Strategy.” In Castro, 147-152. 
Marighella, Carlos. For the Liberation of Brazil. Translated by John Butt and Rosemary Sheed. Edited Richard Gott. Baltimore, MD: Penguin, 1971.

Marighella, Carlos,” Minimanual of the Urban Guerrilla.” In Terror and Urban Guerrillas: A Study of Tactics and Documents, edited by Jay Mallin. Coral Gables, FL: University of Miami Press, 1982.

Metz, Steven and Raymond Millen. Insurgency and Counterinsurgency in the 21st Century: Conceptualizing Threat and Response. Carlisle, PA: Strategic Studies Institute, 2004.

Miller, James A. “Urban Terrorism in Uruguay: The Tupamaros.” In O’Neill, Heaton, and Alberts, 137-190.

Moreno, Jose A. "Che Guevara on Guerrilla Warfare: Doctrine, Practice, and Evaluation.” Comparative Studies in Society and History 12, no. 2 (April 1970): 114-133.

Moss, Robert. The War for the Cities. New York: Coward, McCann \& Geohegan, 1972.

Nacos, Brigitte L. Mass Mediated Terrorism: The Central Role of the Media in Terrorism and Counterterrorism. New York: Rowman and Littlefield, 2007.

Neumann, Peter R. Old and New Terrorism: Late Modernity, Globalization and the Transformation of Political Violence. Malden: Polity Press, 2009.

Norwitz, Jeffrey H., ed. Armed Groups: Studies in National Security, Counterterrorism, and Counterinsurgency. Newport, RI: US Naval War College, 2008.

O’Neill, Bard E. “Insurgency: A Framework for Analysis.” In O’Neill, Heaton, and Alberts, 1-34.

- Insurgency and Terrorism: From Revolution to Apocalypse, 2nd ed. Dulles, VA: Potomac Books, 2005.

- William R. Heaton, and Donald J. Alberts, ed. Insurgency in the Modern World. Boulder, CO: Westview Press, 1980.

Parsa, Misagh. States, Ideologies, and Social Revolutions: A Comparative Analysis of Iran, Nicaragua, and the Philippines. New York: Cambridge University Press, 2000.

Piao, Lin. “Encircling the Cities of the World.” In Laqueur, The Guerrilla Reader, 197-202.

Porzecanski, Arturo C. Uruguay’s Tupamaros: The Urban Guerrilla. New York: Praeger, 1973.

Rasmussen, Maria Jose Mayano. The Military Role in Internal Defense and Security: Some Problems. Monterey, CA: Naval Postgraduate School, 1999.

Rooney, David. Guerrilla: Insurgents, Patriots and Terrorists from Sun Tzu to Bin Laden. London: Brassey, 2004. 
Russell, Charles A., James A. Miller, and Robert E. Hildner. "The Urban Guerrilla in Latin America: A Select Bibliography.” Latin American Research Review 9, no. 1 (Spring 1974): 37-79.

Shultz, Richard. “Virtual Sanctuary Enables Global Insurgency.” In Norwitz, 431-446.

Taw, Jennifer Morrison and Bruce Hoffman. "The Urbanization of Insurgency: Potential Challenges to US Army Operations.” Small Wars and Insurgencies 6, no. 1 (Spring 1995): 68-87.

Tse-tung, Mao, Problems of Strategy in China's Revolutionary War. Selected Works of Mao Tsetung: Vol. I. Peking, China: Foreign Languages Press.

—_. "The Three Stages of the Protracted War.” In Laqueur, The Guerrilla Reader, 189-196.

. On Guerrilla Warfare. Translated by Samuel B. Griffith. Mineola, NY: Dover, 2005.

United Nations Department of Economics and Social Affairs, Population Division. World Urbanization Prospects: The 2014 Revision. New York: United Nations, 2014.

United States Department of the Army. Field Manual 3-24: Insurgencies and Countering Insurgencies. Washington DC: HQ, Department of the Army, 2014.

VV. AA. "Biography of Abraham Guillén: A Libertarian Economist.” Portal Libertario Oaca. Last modified 4 September 2011. Accessed 17 December 2014. http://www.portaloaca .com/historia/biografias/3382-biografia-de-abraham-Guillén-un-economistalibertario.html.

Windrem, Robert. “US Aims to Root Out 'Ungoverned Spaces’ as Hotbeds of Terrorism.” NBC News (August 23, 2014). Accessed 11 February 2015. http://www.nbcnews.com /news/investigations/u-s-aims-root-out-ungoverned-spaces-hotbeds-terrorism-n181941. 